\title{
The Impact of Liquidity and Leverage on Profitability in Industrial Sector in Jordan
}

\author{
Mousa Mohammad Abdullah Saleh ${ }^{1}$, Muneer M. Jaradat ${ }^{2}$, Lu'ay M. Wedyan $^{2}$ \& Haneen Mahmoud Ibrahim Saleh ${ }^{3}$ \\ ${ }^{1}$ Department of Financial and Administrative Sciences, Al-Balqa' Applied University, Jordan \\ 2 Al-Balqa' Applied University, Jordan \\ ${ }^{3}$ Department of Accountancy, The University of Jordan, Jordan \\ Correspondence: Mousa Mohammad Abdullah Saleh, Department of Financial and Administrative Sciences, \\ Al-Balqa' Applied University, Jordan.
}

Received: December 23, 2020

Accepted: February 3, 2021

Online Published: March 5, 2021

doi:10.5430/rwe.v12n1p394

URL: https://doi.org/10.5430/rwe.v12n1p394

\begin{abstract}
Financial leverage is linked to the funding structure in terms of the proportion of debt in the capital structure; the higher the financial leverage is, the more the company depends on debt in its financing structure. On the other hand, the lower the debt is, the more the company relies on equity funding. The company thus decides the optimal funding combination that minimizes the company's capital costs and maximizes shareholder returns.

The aim of this analysis was to quantify the effect of the analysis on the profitability of the Jordanian industrial sector listed on the Amman Stock Exchange during the period (2008-2017) and on a sample of (54) industrial companies to assess the impact of leverage and liquidity. In order to evaluate the data obtained from the actual financial statements of the industrial companies listed on the Amman Stock Exchange, a descriptive and systematic methodology was used. As a result, the statistical conclusion showed that the effect of liquidity and leverage on profitability was a significant result.
\end{abstract}

Keywords: liquidity, leverage, profitability of industrial companies, Amman stock exchange

\section{Introduction}

The 'financial leveraging' concept applies to any borrowing or usage of financial instruments that has the intention of raising the influence of the lender on gains or losses. The debt ratio is often used to describe the debt ratio, since the higher the debt ratio, the larger the influence of financial leverage on the profits and sales of the business. The most important monitoring mechanisms are such percentages, which help to assess the financial structure of a tourism undertaking at a given period in terms of the degree to which it depends on the sources of financing: external or internal. In reality, the lower the company's dependency on loans to support its investments, the lower the company's chance of being exposed to them. Servicing loans and the interest arising from them adds to the depletion of the funds needed from the capital of the business to finance and operate their projects. Investing in low-debt firms is also preferable, since this may be a direct indication of the liquidity position of the firm. The larger the financial leverage level, the higher the profits, and because interest is usually a fixed expense, the yield and gain on shares is enhanced by the financial leverage. (Mahmud and Akter, 2014)

The theory of using the fixed feature of any spending is focused on operational leverage; in the case of operating leverage, the emphasis is on revenue beyond the break-even stage. Sales, then, instead of fixed expenses, are more efficient. In the case of financial leveraging, where work is being undertaken to run the lent capital to obtain a better yield on funding rates, the reliance is on the stability of borrowing costs.

Funding ratios are used to measure the capacity of a company to pay off any of its liabilities in the medium or long term. A high debt level means that the company's leverage is high as well. In the other side, the larger the debt percentage, the greater the degree of doubt about the expected returns of the lenders..

Financial leveraging is graded into two forms. Operating leverage: involves calculating the company's overhead revenue by changing the revenues as a result of the presence of fixed operating costs, when a minor increase in sales contributes to a significant increase in operating profits, while a slight decrease in sales leads to a substantial 
decrease in operating profits due to the use of resources by the facility. The operating leverage is connected to the top of the declaration of profits.

Funding leverage: is the extent that the earnings of a business are influenced by the shift in the amount of operating profit owing to the existence of fixed cost of financing, such as interest on loans. The leverage effect is related to the lower portion of the declaration of sales.

Even if the return on investment is greater than the cost of debt, capital leverage offers the following benefits of raising the return on equity to lenders, the tax benefit related to the right to exclude interest from tax and not to engage in the falsehood of another. There are also a variety of drawbacks if the return on assets is smaller than the cost of borrowing: (Low return on equity, the possibility of creditors gaining control of the entity).

It should be remembered that all organizational and financial increases are focused around the concept of improving profitability by taking advantage of the fixed characteristics of such investments, since the rise in operational revenue contributes to a higher increase in profitability due to the actions of fixed costs, which may not adjust with the increase in sales within a certain range. Profitability is enhanced in the case of financial flexibility by investing at comparatively fixed rates and operating funds to generate a greater yield than the borrowing rate (Berger and Bonaccorsi, 2006).

Financial leveraging relates to the usage of borrowed funds by third parties to optimize operating benefit before interest and taxes, as the ratio of loans to total liabilities can be described. (2014, by Borhan et al). Most of these studies have come to an important conclusion that "reaching an ideal capital structure for the project is based on the balance between benefits and costs when deciding on the use of financial leverage"

Industrial corporations' operations have advanced dramatically and are the key supports of the economy and of the capital and investment complex, however danger can impact this business, resulting in financial losses. Many factors influence the key goal of investment in this field is to attain the greatest possible profitability and, hence, the concept of research is to study the impact of any of these variables on the profitability of manufacturing firms. The effects of debt variables (debit ratio, credit ratio, interest coverage ratio) and liquidity (current ratio, working capital, quick ratio) and (return on assets, return on equity, E / P) have been evaluated as a measure of profitability. Profitability includes the profitability of divisions of industrial companies. The industrial industry, providing the government with a supply of capital and security for the economy, is one of the most significant sectors in the economy. (2016-Fiador).

\section{Literature Review}

The benefit of the financial leverage is the tax advantage of the borrowing, which is focused on the fact that all the interests and commissions charged on the loans used in the lending are assumed to be tax costs deducted before the taxable profit is achieved and thus the amount of tax due is reduced; on the other hand, the cost of utilizing the financial leverage is represented by the failure to service the mortgage, which is $r$ In addition to the large procuration costs involved with the lenders, this leads the business to the possibility of bankruptcy. This is expressed by the the monitoring and supervision strength of such issues within the organization by limitations imposed by the loan agreements negotiated between the business and the lenders, contributing to a reduction in the versatility of the project's existing capital structure. On the basis of the above, if an establishment requires sufficient funding to extend and prosper, the first solution for these businesses to receive their cash needs is to raise the amount of foreign financing, or to go to the financial sector to increase the issued resources, or to obtain these funds by a combination that involves possession of funds and borrowing assets. Companies stop investing alternatives by rising capital and this choice is more risky than long-term debt instruments (McMahon and Stanger, 1996).

Debt service capacity relates to the willingness of the facility under a given debt schedule to satisfy the prescribed fixed payments, which therefore implies the ability to pay interest and recover the principal. Coverage levels are used to assess the willingness of hospitality businesses to satisfy their fixed obligations. In regards to the company's capacity to pay existing and planned obligations, stakeholders are very involved in these ratios. The smaller the ratio of coverage, the more threats the business is likely to encounter. They would be in a state of cash deficit, contributing to bankruptcy in certain cases.

A research (Makori and Jagongo, 2013) found that, according to the Tobins model, leverage has an adverse effect on conventional success metrics (ROA, ROS and ROE) and the adverse effects of financial leverage on the market valuation of the institution. The reliance of major public profit hospitals on lent funds substantially lowers their expenses and contributes to an increase in the rate of return on investment. Reliance on funding sources of ownership decreases the amount of return on investment gained and, on the other hand, raises the level of financing expenses 
and the level of tax. There is a beneficial balance between return on investment, net profit and return on capital operating for financial leverage, and a detrimental relationship with return on equity and financial leverage.

Financial leveraging is the degree or proportion used to fund a portion of properties through debt funding (Hanafi, 2008).

Financial leverage is the usage of the resources of another in lending in order to raise operational income before interest and taxes (Al-Sayeh, 2014(It shows that financial leverage would show various relationships with profitability based on the proportion of debt used and that short-term debt and total debt have a positive relationship with profitability, whereas long-term debt has a negative relationship with profitability

It is the loans-to-to-total liabilities ratio (Yahyawi, 2002), and it relies on investing to finance the business's operations in order to achieve a profit that raises the shareholders' profits (Nurlina and Muda, 2017).

\subsection{The Relationship Between Financing Structure and Financial Leverage}

The sources of financing and their classifications differ, but they are classified in source terms into: internal sources by possession, and external sources by debt. They are split down into short-term, medium-term, and long-term outlets in terms of the term.

When the self-funding sources are inadequate to satisfy and support their requirements, or when they wish to utilize more of them for several purposes, such as growth or increasing viability, businesses turn to looking for other sources, so the financing arrangement is a combination of ownership money and leverage, whether long-term or short-term. The financial leverage relationship is related to the funding framework in terms of the proportion of debt in the capital structure; the greater the financial leverage is, the more the business depends on debt in its financing structure. In the other side, the bigger the debt is, the more the business relies on equity funding. The organization must also evaluate the optimum funding balance that minimizes the capital costs of the company and maximizes shareholder returns (Samo and Murad, 2019).

\subsection{Meaning of "Degree of Financial Leverage"}

The degree of financial leverage is related to the financing structure of the companies, which results from the existence of fixed benefits for the company. The degree of financial leverage is measured as follows:

(EBIT) earnings before interest and taxes

Electronic benefit transfer (EBT)

The degree of financial flexibility tests the resilience or tolerance of the EBIT adjustment due to the pre-tax benefit shift (Chandra, 2005, p: 26.6).

For instance, if the degree of financial leverage for a corporation is believed to be (2), this implies that a rise in profit before interest and tax by (1\%) would result in a change in profit before tax by (1\%) (2 percent).

In the case of financial leveraging, the potential to boost debt performance at a comparatively fixed expense and the operation of these loans in the activities of the business generates a greater return than the debt cost, given that the company is capable of doing so. (Talha et al, 2010) shows that when the yield on investment is greater than the expense of assumption, financial leverage is reached. It has the following advantages: raising the yield on the equity of lenders as a consequence of the gap between the funding expense and the return on investment, retaining institutional leverage so borrowers have no management voice, and not splitting the gains made with others. In addition, borrowing wisely helps the company to develop credibility in the markets, and this is something that is significant, particularly as further borrowing is required.

\subsection{Risks of Leverage}

Financial danger involves the fluctuation of the post-tax net benefit of the residual return of investors (common shareholders) as a consequence of the usage of fixed-cost forms of finance, such as interest, the probability of failing to repay the principal loan, or interest, or both, if due. It is a debt-linked possibility. Logically, the larger the liability level in the asset finance structure, the higher the degree of risk. Indeed, the danger resides not in the debt itself, but rather in the likelihood of a lower amount of income, which is supposed to be reached below the level of interest charged on the debt, and this suggests the company's exposure as a consequence of a decrease below the rate, which is a financial risk in itself.

The value of liquidity stems from the assumption that the establishment's strong liquidity contributes to a reduction in the threats it poses. It also reflects the willingness of the facility to internally fund its expenses and eliminates the case of being required to borrow (Wasiuzzaman, 2018). 
Liquidity is significant because of its impact on the estimation of the maturity of the debt, as well as the proportion of the debt in the funding system. The greater the degree of availability of the properties, the higher it can be counted on to service the loans, and the fewer liquid assets, the less flexible it is to serve these loans, in addition to how simple or difficult it is to mortgage the asset, the more usable assets that are sufficient as leverage to promote the financing process, the more the process of securing the req

The Liquidity Effect on Profitability, an explanatory review of the financial sector during 2008-2017, was analyzed (Jing Xi, 2018). The recession in 2007-2008 prompted the government and regulators to tighten the banking sector to reduce the effects of the crisis. One field of focus was liquidity for banks' continued activity. 'Glory, 2017' 'Effect of Leverage on Efficiency of Companies: A Nii Report'

"Gharios, 2016" "The Economic Of Liquidity And Leverage On The Financial Performance Of Mena \& GCC Listed Companies" The time series and the unintentional effect on the profitability of businesses of liquidity, financial leverage and geogra

'In 2016, Antonio Iacobelli calculated the profitability of the 16 banks using the data from the plates for the period 1980 to 2015, since the fixed effects and the results indicate that the characteristics of the bank, the nature of the market and the macroeconomic variables are essential to understand the profitability of the global banks. External alteration and external considerations (Ahmad, 2015)

Ganic, 2014, analyses the exposure of banks to liquidity risk for 17 out of 28 commercial banks in Bosnia and Herzegovina. The study found that several of the examined variables have a certain effect on assessing the extent of bank exposure to liquidity risk accordingly, in order to test the relevance of numbers and illustrative capacity of the variables using various data analysis techniques.

Document review, Lartey, 2013, is the primary indicator adopted for the study's secondary data set. Examination of liquidity and profitability using time series. This report, which lasted from 2005-2010, revealed that the liquidity and profitability of these banks decreased and noticed that there was a poor association between the liquidity and profitability of listed banks

\section{Main Problem}

The problem in this research can be summarizing as follows:

There is an impact of liquidity in the profitability of industrial companies.

There an impact of leverage on the profitability in industrial companies.

\section{Methodology}

The purpose of the analysis was to measure the profitability effect of liquidity and financial leverage on the public industrial joint-stock companies listed on the Amman Financial Exchange. During the analysis, a deliberate survey of 54 businesses gathered financial details and derived financial metrics from them for the years 2008 to 2017. Extracting ratios and financial metrics from them, as liquidity was calculated by Current Ratio, Working Capital, Fast Ratio, as such ratios are considered to be the most significant for measuring the liquidity of the firm, whereas debit ratio, equity ratio, interest coverage ratio and profitability of the company were measured for measuring the financial leverage.

The report used a comprehensive and structured method to analyze the data obtained from the individual financial statements of the Amman Stock Exchange-listed manufacturing firms.

During the research, financial analysis models of variables were used, and the influence of independent variables (liquidity and financial leverage) on the dependent variable (profitability) was evaluated through the derived data, and theories indicating the presence of potential causal associations were tested during the review, and the primary data were obtained through Arabic and foreign analyses.

\subsection{The Hypotheses}

Ho1: There is no statistically significant impact of liquidity ratio on profitability of the industrial companies.

Ho2: There is no statistically significant impact of the leverage on the profitability of industrial companies.

Ho3: There is no statistically significant impact for both of the liquidity and leverage on profitability of the industrial companies. 


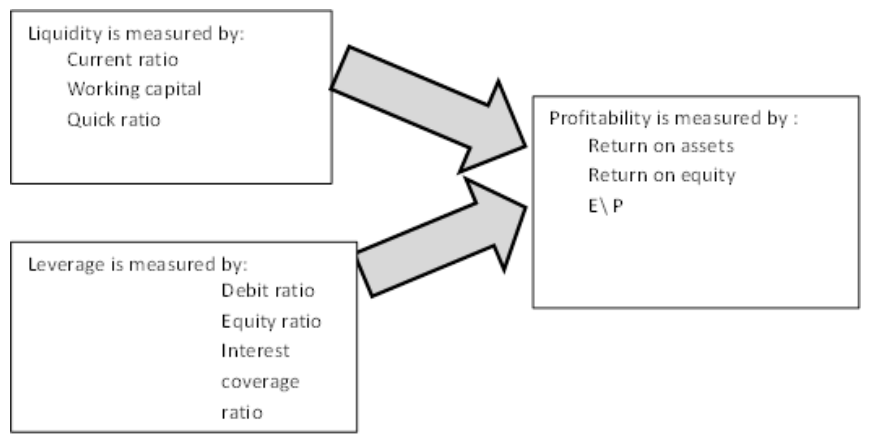

Figure 1. Flowchart of this research which consists of the following components

\section{Results}

Table 1. Descriptive statistics

\begin{tabular}{llllll}
\hline Variables & Mean & Median & Maximum & minimum & Stander deviation \\
\hline Return on Assets \% & 7.357 & 6.595 & 16.06 & .85 & 5.003 \\
\hline Return on Equity \% & 10.286 & 9.195 & 24.74 & 1.15 & 7.395 \\
\hline E/P & 0.257 & 0.24 & .58 & .03 & 0.171 \\
\hline Debit Ratio \% & 32.4 & 31.48 & 37.92 & 28.78 & 2.776 \\
\hline Equity Ratio \% & 67.6 & 68.52 & 71.22 & 62.08 & 2.776 \\
\hline Interest Coverage Ratio (Times) & 10.699 & 9.37 & 22.45 & 2.55 & 6.323 \\
\hline Current Ratio (Times) & 1.886 & 1.88 & 2.14 & 1.62 & 0.157 \\
\hline Working Capital (JD) & 2.814 & 2.655 & 3.5 & 2.52 & 0.335 \\
\hline Quick Ratio & 1.33 & 1.3 & 1.59 & 1.22 & 0.121 \\
\hline
\end{tabular}

As seen in this graph, the average number of companies (ROA) is 7.357. The mean valuation of companies deviated from the aggregate degree of profitability is roughly 5,003. The total value of (ROE) is 10,286. The minimum and maximum values of (ROE) are 1.15 and 24.74 . The average (E/P) is.257 and the minimum and maximum values are.03 and.58.

Table 2. Person Correlation Matrix between independent variable and dependent variable

\begin{tabular}{lllll}
\hline \multirow{2}{*}{ Current ratio } & & Return on assets & Return on equity & E\P \\
\cline { 2 - 5 } & Pearson Correlation & .370 & .288 & .310 \\
\cline { 2 - 5 } Working capital & Sig. & .293 & .420 & .383 \\
\cline { 2 - 5 } & Pearson Correlation & .246 & .330 & .323 \\
\cline { 2 - 5 } Quick ratio & Sig. & .494 & .352 & .363 \\
\cline { 2 - 5 } & Pearson Correlation & $.692^{*}$ & .630 & $.651^{*}$ \\
\hline \multirow{2}{*}{ Debit ratio } & Sig. & .027 & .051 & .042 \\
\cline { 2 - 5 } & Pearson Correlation & .411 & .485 & .458 \\
\hline \multirow{2}{*}{$\begin{array}{l}\text { Interest } \\
\text { ratio }\end{array}$} & Sig. & .238 & .155 & .183 \\
\hline
\end{tabular}

*Correlation is significant at the $(\alpha \leq 0.05)$

$* *$ Correlation is significant at the $(\alpha \leq 0.01)$ 
Ho1: There is no statistically significant impact of liquidity ratio on profitability (Return on assets).

To sure this hypothesis we applied the multiple regressions between the independent variable (current ratio, working capital, and quick ratio) and dependent variable (return on assets), as shown below:

Table 3.The results for multiple regressions

\begin{tabular}{|c|c|c|c|c|c|c|c|c|c|c|}
\hline \multirow[t]{3}{*}{$\mathbf{R}$} & \multirow{3}{*}{$\begin{array}{l}\mathbf{R} \\
\text { Square }\end{array}$} & \multirow{3}{*}{$\begin{array}{l}\text { Adjusted } \\
\text { R Square }\end{array}$} & \multirow[t]{3}{*}{$\mathbf{F}$} & \multirow[t]{3}{*}{ Sig* } & \multicolumn{6}{|c|}{ Regression coefficients } \\
\hline & & & & & \multicolumn{3}{|c|}{$\begin{array}{l}\text { Unstandardized } \\
\text { Coefficients }\end{array}$} & \multicolumn{2}{|c|}{ Standardized } & \\
\hline & & & & & Domain & $\boldsymbol{\beta}$ & Std. Error & Beta & $\mathbf{T}$ & Sig* \\
\hline \multirow[t]{4}{*}{0.84} & 0.710 & 0.565 & 4.900 & $0.047 *$ & Constant & -.767 & .294 & & -2.611 & $.040 *$ \\
\hline & & & & & $\begin{array}{l}\text { Current } \\
\text { ratio }\end{array}$ & .135 & .149 & .426 & .904 & .401 \\
\hline & & & & & $\begin{array}{l}\text { Working } \\
\text { capital }\end{array}$ & .101 & .050 & .678 & 2.011 & .091 \\
\hline & & & & & Quick ratio & .227 & .146 & .558 & 1.558 & .170 \\
\hline
\end{tabular}

* Statistically significant at the level of statistical significance $(\alpha \leq 0.05)$

We show in Table 3 the following:

The value $(F=4.9)$ and statistically significant $(0.047)$ is less than the level of statistical significance $(\alpha \leq 0.05)$, Thus, a multiple linear regression model is suitable for measuring the causal relationship between the independent variable (current ratio, working capital, and quick ratio) and dependent variable (return on assets). A summary of the Model Summary analysis of multiple linear regressions.

The value of the correlation coefficient between the independent variable (current ratio, working capital, and quick ratio) and dependent variable (return on assets) was (0.843), the value of the coefficient of determination (R2) (0.710), and that the value of the adjusted determination coefficient (Adjusted R2) (0.565) which indicates that the independent variable current ratio, working capital, and quick ratio) was able to explain (56.5\%) of the changes in the dependent variable (return on assets) and the rest attributed to other factors.

There are not a statistical significance for the coefficient of multiple linear regression equation related to the independent variable current ratio, working capital, and quick ratio) and dependent variable (return on assets).

Ho2: There is no statistically significant impact of liquidity ratio on profitability (Return on equity).

To sure this hypothesis we applied the multiple regressions between the independent variable (current ratio, working capital, and quick ratio) and dependent variable (return on equity), as shown below:

Table 4. The results for multiple regression

\begin{tabular}{|c|c|c|c|c|c|c|c|c|c|c|}
\hline \multirow[t]{3}{*}{$\mathbf{R}$} & \multirow{3}{*}{$\begin{array}{l}\mathbf{R} \\
\text { Square }\end{array}$} & \multirow{3}{*}{$\begin{array}{l}\text { Adjusted } \\
\text { R Square }\end{array}$} & \multirow[t]{3}{*}{$\mathbf{F}$} & \multirow[t]{3}{*}{ Sig* } & \multicolumn{6}{|c|}{ Regression coefficients } \\
\hline & & & & & & \multicolumn{2}{|c|}{$\begin{array}{l}\text { Unstandardized } \\
\text { Coefficients }\end{array}$} & \multicolumn{3}{|c|}{ Standardized } \\
\hline & & & & & Domain & $\boldsymbol{\beta}$ & Std. Error & Beta & $\mathbf{T}$ & Sig* \\
\hline \multirow[t]{4}{*}{0.83} & 0.694 & 0.541 & 4.536 & 0.055 & Constant & -1.149 & .446 & & -2.574 & .052 \\
\hline & & & & & Current ratio & .199 & .227 & .423 & .875 & .415 \\
\hline & & & & & $\begin{array}{l}\text { Working } \\
\text { capital }\end{array}$ & .165 & .076 & .749 & 2.165 & .074 \\
\hline & & & & & Quick ratio & .311 & .222 & .516 & 1.402 & .211 \\
\hline
\end{tabular}

* Statistically significant at the level of statistical significance $(\alpha \leq 0.05)$ 
We show in Table 4 the following:

The value $(F=4.536)$ and statistically significant $(0.055)$ is more than the level of statistical significance $(\alpha \leq 0.05)$, Thus, a multiple linear regression model is not suitable for measuring the causal relationship between the independent variable (current ratio, working capital, and quick ratio) and dependent variable (return on equity).

Ho3: There is no statistically significant impact of liquidity ratio on profitability (E\P).

To sure this hypothesis we applied the multiple regressions between the independent variable (current ratio, working capital, and quick ratio) and dependent variable (E\P), as shown below:

Table 5. The results for multiple regressions

\begin{tabular}{|c|c|c|c|c|c|c|c|c|c|c|}
\hline \multirow[t]{3}{*}{$\mathbf{R}$} & \multirow{3}{*}{$\begin{array}{l}\mathbf{R} \\
\text { Square }\end{array}$} & \multirow{3}{*}{$\begin{array}{l}\text { Adjusted } \\
\text { R Square }\end{array}$} & \multirow[t]{3}{*}{$\mathbf{F}$} & \multirow[t]{3}{*}{ Sig* } & \multicolumn{6}{|c|}{ Regression coefficients } \\
\hline & & & & & \multirow[b]{2}{*}{ Domain } & \multicolumn{2}{|c|}{$\begin{array}{l}\text { Unstandardized } \\
\text { Coefficients }\end{array}$} & \multicolumn{2}{|c|}{ Standardized } & \multirow[b]{2}{*}{ Sig* } \\
\hline & & & & & & $\boldsymbol{\beta}$ & Std. Error & Beta & $\mathbf{T}$ & \\
\hline \multirow[t]{4}{*}{0.851} & \multirow[t]{4}{*}{0.724} & \multirow[t]{4}{*}{0.586} & \multirow[t]{4}{*}{5.248} & \multirow[t]{4}{*}{$0.041^{*}$} & Constant & -2.727 & .983 & & -2.775 & $.032 *$ \\
\hline & & & & & Current ratio & .490 & .500 & .451 & .980 & .365 \\
\hline & & & & & $\begin{array}{l}\text { Working } \\
\text { capital }\end{array}$ & .390 & .168 & .762 & 2.317 & .060 \\
\hline & & & & & Quick ratio & .726 & .488 & .520 & 1.489 & .187 \\
\hline
\end{tabular}

* Statistically significant at the level of statistical significance $(\alpha \leq 0.05)$

We show in Table 5 the following:

The value $(F=5.248)$ and statistically significant $(0.041)$ is less than the level of statistical significance $(\alpha \leq 0.05)$, Thus, a multiple linear regression model is suitable for measuring the causal relationship between the independent variable (current ratio, working capital, and quick ratio) and dependent variable (E\P). A summary of the Model Summary analysis of multiple linear regressions.

The value of the correlation coefficient between the independent variable current ratio, working capital, and quick ratio) and dependent variable (E\P) was (0.851), the value of the coefficient of determination (R2) (0.724), and that the value of the adjusted determination coefficient (Adjusted R2) (0.586) which indicates that the independent variable current ratio, working capital, and quick ratio) was able to explain (58.6\%) of the changes in the dependent variable $(\mathrm{E} \backslash \mathrm{P})$ and the rest attributed to other factors.

There are not a statistical significance for the coefficient of multiple linear regression equation related to the independent variable current ratio, working capital, and quick ratio) and dependent variable (E/P).

Ho4: There is no statistically significant impact of liquidity ratio on leverage (Return on assets).

To sure this hypothesis we applied the multiple regressions between the independent variable (Debit ratio, Interest coverage ratio) and dependent variable (return on assets), as shown below:

Table 6. The results for multiple regressions

\begin{tabular}{|c|c|c|c|c|c|c|c|c|c|c|}
\hline & \multirow{3}{*}{$\begin{array}{l}\mathbf{R} \\
\text { Square }\end{array}$} & \multirow{3}{*}{$\begin{array}{l}\text { Adjusted } \\
\text { R Square }\end{array}$} & \multirow[t]{3}{*}{$\mathbf{F}$} & \multirow[t]{3}{*}{ Sig* } & \multicolumn{6}{|c|}{ Regression coefficients } \\
\hline & & & & & \multicolumn{3}{|c|}{$\begin{array}{l}\text { Unstandardized } \\
\text { Coefficients }\end{array}$} & \multicolumn{2}{|c|}{ Standardized } & \\
\hline & & & & & Domain & $\boldsymbol{\beta}$ & Std. Error & Beta & $\mathbf{T}$ & Sig* \\
\hline \multirow[t]{3}{*}{0.996} & 0.993 & 0.991 & 473.36 & $0.00^{*}$ & Constant & -.152 & .020 & & -7.531 & $.000 *$ \\
\hline & & & & & $\begin{array}{l}\text { Debit } \\
\text { ratio }\end{array}$ & .459 & .064 & .237 & 7.201 & $.000^{*}$ \\
\hline & & & & & $\begin{array}{l}\text { Interest } \\
\text { coverage } \\
\text { ratio }\end{array}$ & .007 & .000 & .924 & 28.032 & $.000 *$ \\
\hline
\end{tabular}

* Statistically significant at the level of statistical significance $(\alpha \leq 0.05)$ 
We show in Table 6 the following:

The value $(\mathrm{F}=473.36)$ and statistically significant $(0.00)$ is less than the level of statistical significance $(\alpha \leq 0.05)$, Thus, a multiple linear regression model is suitable for measuring the causal relationship between the independent variable (Debit ratio, Interest coverage ratio) and dependent variable (return on assets). A summary of the Model Summary analysis of multiple linear regressions.

The value of the correlation coefficient between the independent variable (Debit ratio, Interest coverage ratio) and dependent variable (return on assets) was (0.996), the value of the coefficient of determination (R2) (0.993), and that the value of the adjusted determination coefficient (Adjusted R2) (0.991) which indicates that the independent variable (Debit ratio, Interest coverage ratio) was able to explain (99.1\%) of the changes in the dependent variable (return on assets) and the rest attributed to other factors.

There are a statistical significance for the coefficient of multiple linear regression equation related to the independent (Debit ratio, Interest coverage ratio), where the value $(T=7.201,28.032)$ respectively, which shows the impact of the effect (Debit ratio, Interest coverage ratio) on return on assets. Thus, there are significant significance for the coefficient of multiple linear regression equation, which were $(0.237,0.924)$ respectively, are a positive effect.

Ho4: There is no statistically significant impact of liquidity ratio on leverage (Return on equity).

To sure this hypothesis we applied the multiple regressions between the independent variable (Debit ratio, Interest coverage ratio) and dependent variable (return on equity), as shown below:

Table 7. The results for multiple regressions

\begin{tabular}{|c|c|c|c|c|c|c|c|c|c|c|}
\hline \multirow[t]{3}{*}{$\mathbf{R}$} & \multirow{3}{*}{$\begin{array}{l}\text { R } \\
\text { Square }\end{array}$} & \multirow{3}{*}{$\begin{array}{l}\text { Adjusted R } \\
\text { Square }\end{array}$} & \multirow[t]{3}{*}{$\mathbf{F}$} & \multirow[t]{3}{*}{ Sig* } & \multicolumn{6}{|c|}{ Regression coefficients } \\
\hline & & & & & \multicolumn{3}{|c|}{$\begin{array}{l}\text { Unstandardized } \\
\text { Coefficients }\end{array}$} & \multicolumn{3}{|c|}{ Standardized } \\
\hline & & & & & Domain & $\boldsymbol{\beta}$ & Std. Error & Beta & $\mathbf{T}$ & Sig* \\
\hline \multirow[t]{3}{*}{0.992} & 0.983 & 0.978 & 205.04 & $0.00^{*}$ & Constant & -.300 & .045 & & -6.666 & $.000 *$ \\
\hline & & & & & Debit ratio & .913 & .142 & .320 & 6.415 & $.000^{*}$ \\
\hline & & & & & $\begin{array}{l}\text { Interest } \\
\text { coverage } \\
\text { ratio }\end{array}$ & .010 & .001 & .880 & 17.663 & $.000 *$ \\
\hline
\end{tabular}

* Statistically significant at the level of statistical significance $(\alpha \leq 0.05)$

We show in Table 7 the following:

The value $(F=205.04)$ and statistically significant $(0.00)$ is less than the level of statistical significance $(\alpha \leq 0.05)$, Thus, a multiple linear regression model is suitable for measuring the causal relationship between the independent variable (Debit ratio, Interest coverage ratio) and dependent variable (return on equity). A summary of the Model Summary analysis of multiple linear regressions.

The value of the correlation coefficient between the independent variable (Debit ratio, Interest coverage ratio) and dependent variable (return on equity) was (0.992), the value of the coefficient of determination (R2) (0.983), and that the value of the adjusted determination coefficient (Adjusted R2) (0.978) which indicates that the independent variable (Debit ratio, Interest coverage ratio) was able to explain (97.8\%) of the changes in the dependent variable (return on equity) and the rest attributed to other factors.

There are a statistical significance for the coefficient of multiple linear regression equation related to the independent (Debit ratio, Interest coverage ratio), where the value $(T=6.415,17.663)$ respectively, which shows the impact of the effect (Debit ratio, Interest coverage ratio) on return on equity. Thus, there are significant significance for the coefficient of multiple linear regression equation, which were $(0.32,0.88)$ respectively, are a positive effect.

Ho4: There is no statistically significant impact of liquidity ratio on leverage (E/P).

To sure this hypothesis we applied the multiple regressions between the independent variable (Debit ratio, Interest coverage ratio) and dependent variable (E/P), as shown below: 
Table 8. The results for multiple regressions

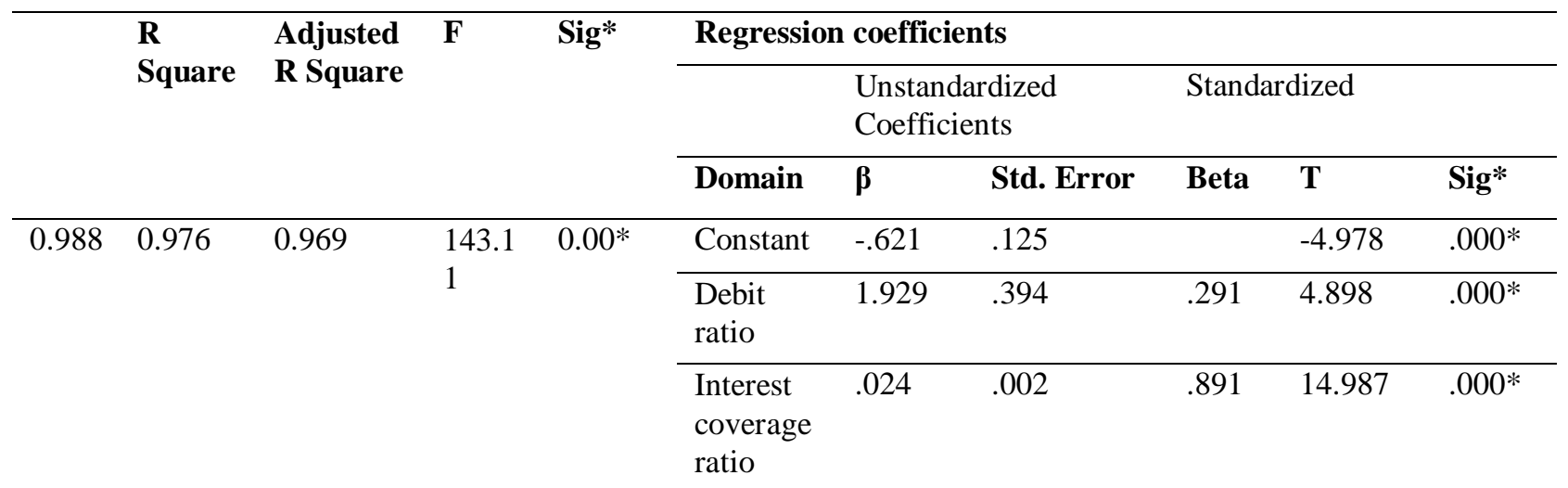

* Statistically significant at the level of statistical significance $(\alpha \leq 0.05)$

We show in Table 8 the following:

The value $(F=143.11)$ and statistically significant $(0.00)$ is less than the level of statistical significance $(\alpha \leq 0.05)$, Thus, a multiple linear regression model is suitable for measuring the causal relationship between the independent variable (Debit ratio, Interest coverage ratio) and dependent variable (E/P). A summary of the Model Summary analysis of multiple linear regressions.

The value of the correlation coefficient between the independent variable (Debit ratio, Interest coverage ratio) and dependent variable (E/P) was (0.988), the value of the coefficient of determination (R2) (0.976), and that the value of the adjusted determination coefficient (Adjusted R2) (0.969) which indicates that the independent variable (Debit ratio, Interest coverage ratio) was able to explain (96.9\%) of the changes in the dependent variable (E/P) and the rest attributed to other factors.

There are a statistical significance for the coefficient of multiple linear regression equation related to the independent (Debit ratio, Interest coverage ratio), where the value $(\mathrm{T}=4.898,14.987)$ respectively, which shows the impact of the effect (Debit ratio, Interest coverage ratio) on E/P. Thus, there are significant significance for the coefficient of multiple linear regression equation, which were $(0.291,0.891)$ respectively, are a positive effect.

\section{Conclusion}

The key aim of this analysis was to examine and clarify the effects of the liquidity and leverage levels on the viability of the Jordanian manufacturing sector. This study describes the effects of liquidity and debt levels on prosperity and is focused on data from 54 manufacturing companies in the sector during the last 10 years (2008-2017). Industrial data in Jordan Data was gathered from the Amman Stock Exchange for all firms in the Jordanian industrial market. A basic linear regression analysis was used to evaluate the hypotheses. The findings revealed the effects of liquidity and leveraging on profitability.

Liquidity has a double effect on the composition of money. The relationship between liquidity and the leverage level may be optimistic or negative, whereas the relationship with profitability in general is positive. Establishments with strong liquidity thus have the potential to satisfy due commitments, rendering them more capable of reducing the debt level and the leverage ratio, thus making it possible for them to borrow.

As the liquidity of the establishment reduces, the short-term obligations accumulate, which would boost both the liability and the leverage level, it would be impossible to borrow. The negative relationship between them is therefore predicted. In the other side, the constant and unsustainable rise in the liquidity of the establishment suggests that it can not utilize the available liquidity to produce income and thus decreases the ability of the establishment to create profits.

Financing by investing ends in-the so-called-financial leverage. It is the borrowing or usage of financial assets that results in an improvement in the effect of gains or losses on the lender and is also used to characterize debt ratios. The higher the debt rates, the stronger the effect of the financial leverage on the company's earnings. These ratios are among the most critical tools that help to determine the funding structure of the facility at a given point, in terms of the degree of its reliance on sources of financing, whether internal or external. In general, the less the facility depends on loans to fund its facilities, the less risk-exposed the facility would be, since serving the loan and its needs 
will contribute to the depletion of the cash capital capacity of the facility required to run its ventures. Financial debt helps the lender to raise the potential return further than ever, but the expected loss is still larger if the investment becomes worthless. It is then important to pay off the principal sum lent, as well as all interest on the loan.

In both cases; before settling on leverage, companies can review the extent of performance of their activities and funding operations and the environmental factors affecting them. Financial leveraging can contribute to the greatest results when operations and funding procedures are effective and when the circumstances around the plant are acceptable, it may lead to unfavorable consequences if things go wrong.

Among the essential decisions made by the financial managers is to evaluate the optimum balance of funding outlets open to the facility (borrowed and owned) in a manner that produces the optimal use for them and maximizes returns and income for investors. Any institutions-when their existing means of funding (ownership) are insufficient-recourse to foreign financing (borrowing). In this respect, institutions must take into consideration the amount of danger inherent in this funding.

Establishments that are unable to satisfy their contractual commitments would be rocked by their financial role on the economy, meaning that they have to balance the degree of financial leverage utilized in their investment activities. That is why it is one of the effective capital structure policies, that is, a rise or reduction in the financial debt of the company would contribute to a shift in the capital structure (known as capital restructuring) which will take effect when the facility substitutes one capital with another and holds the facility's assets unchanged.

Financial danger reflects a fluctuation of the valuation of the earnings and the remaining return of the investors (common stock holders). This is part of the income arising from the usage of fixed-cost forms of finance (such as interest) and the nature of the risk that the corporation will not be able to cover the principal, interest or both in due time. As a consequence, these threats are debt-related. As a result, the larger the liability amount of the asset finance system of the establishments, the higher the level of risk. This threats do not treat debt as a primary risk, but rather the probability of a lower amount of benefit projected to be obtained than the cost of interest charged on the debt. This means that the business is vulnerable to losses due to a decline in return below the amount of expenses it bears, and this in itself is a financial danger.

Financial danger is tied to the funding judgment, which implies that it refers to the option of an entity's financial framework. Financial borrowing contributes to a large amount of danger posed by lenders, which leads to a rise of the obligations and liabilities of the establishment which raises the likelihood of the facility being unable to service the debts. That is why financial management is attempting to coordinate the effect of borrowing and the return on land rights, in addition to the degree of danger that the owners face. We may assume that the equilibrium between debt and ownership contributes to an optimum combination of the financial system, which in turn lowers funding costs.

The theory of financial leveraging is based on the concept of improving profitability by investing at a comparatively low fixed cost and operating the invested funds in the facility's activities to generate a greater return than borrowing costs, believing (with a view to the end) that the facility has the potential to do so.

The gap between existing assets and current liabilities is the net working capital funded by long-term sources of funding, which may impact the performance of the business due to the rise in costs incurred by the company. As a consequence, the management of the firms and those concerned shall pay due attention to profitability and net working capital with a view to optimizing financial efficiency.

Companies should take into account the conservation of sufficient liquidity for their activities, holding them at a reasonable risk range and optimizing the value of the company (Samuel, 2016).

Profitability levels calculate the effectiveness of corporate governance in generating profit in comparison to revenue, properties and rights of shareholders. It is a significant metric for management, customers, creditors and other stakeholders that allows management to check and evaluate the performance of its different policies. Investors typically search for lucrative ways to guide their capital, whereas lenders feel comfortable while lending to a business that achieves more income than they usually do.

Profitability ratios express the degree of productivity with which the organization takes its spending and funding choices. Investment judgment is the decision made by the organization to utilize its existing capital for the purchase of its different properties. The funding decision reveals how to select the best sources of financing to fund the investments at the lowest expense (Maswada and Khashan, 2016; Jahmani et al,2020; ALsarayreh et al,2011). Profitability ratios provide metrics and measurements of the performance of the company in raising income, as they 
provide valuable proof of the efficiency of the business's activities. Profitability levels demonstrate the cumulative impact of liquidity, wealth control and leverage on operating outcomes.

\section{References}

Agriculture, E. I. N. (1921). Scientific papers. Science, 54(1392), 195-196. https://doi.org/10.1126/science.54.1392.195

Ahmad, N., Salman, A., \& Shamsi, A. F. (2015). Impact of financial leverage on firms' profitability: an investigation from cement sector of Pakistan. Research Journal of Finance and Accounting, 6(7), 75-81.

Akter, A., \& Mahmud, K. (2014). Liquidity-Profitability relationship in Bangladesh banking industry. International Journal of Empirical Finance, 2(4), 143-151.

ALsarayreh, M., Jawabreh, O., Jaradat, M., \& ALamro, A. (2011). Technological impacts on effectiveness of accounting information systems (AIS) applied by aqaba tourist hotels. European Journal of Scientific Research, 59(3), 361-369.

Berger, A. N., \& Bonaccorsi di Patti, E. (2006). Capital structure and firm performance: a new approach to testing agency theory and an application to the banking industry. Journal of Banking and Finance, 30(4), 1065-1102.

Borhan, H., Naina Mohamed, R., \& Azmi, N. (2014). The impact of financial ratios on the financial performance of a chemical company: the case of Lyondellbasell industries. World Journal of Entrepreneurship, Management and Sustainable Development, 10(2), 323-332.

Bwacha, C. R., \& Xi, J. (2018). The impact of liquidity on profitability: an explanatory study of the banking sector between 2008 and 2017.2 Retrieved https://pdfs.semanticscholar.org/3116/4b2e50d674adcabe37007746836fe482e20f.pdf

Fiador, V. (2016). Does corporate governance influence the efficiency of working capital management of listed firms: evidence from Ghana. African Journal of Economic and Management Studies, 7(4), 482-496.

Ganii, M. (2014). An empirical study on liquidity risk and its determinants in Bosnia and Herzegovina. SSRN Electronic Journal, (52), 157-184. https://doi.org/10.2139/ssrn.2510743

Gharios, R., Hamdar, B., \& Seissian, L. A. (2016). The economic impacts of liquidity and leverage on the financial performance of mena \& gcc listed companies. International Journal of Economics, Commerce and Management, IV(10), 1110-1125.

Hasanhodzic, J., \& Lo, A. W. (2019). On black's leverage effect in firms with no leverage. The Journal of Portfolio Management, 46(1), 106-122. https://doi.org/10.3905/jpm.2019.46.1.106

Iacobelli, A. (2015). Determinants of profitability: empirical evidence from the largest global banks. Retrieved from http://www.albany.edu/honorscollege/files/AntonioIacobelli.pdf

Jahmani, A., Bourini, I., \& Jawabreh, O. A. (2020). The relationship between service quality, client satisfaction, perceived value and client loyalty: a case study of fly emirates. Cuadernos De Turismo, (45), 219-238. https://doi.org/10.6018/turismo.45.426101

Lartey, V. C., Antwi, S., \& Boadi, E. K. (2013). The relationship between liquidity and profitability of listed Banks in Ghana. International Journal of Business and Social Science, 4(3), 48-56.

Makori, D. M., \& Jagongo, A. (2013). Working capital management and firm profitability: empirical evidence from manufacturing and construction firms listed on Nairobi securities exchange, Kenya. International Journal of Accounting and Taxation, 1(1), 1-14.

McMahon, R. G. P., \& Stanger, A. M. J. (1996). The small enterprise financial objective function: an exploratory study using informed scholarly opinion. Journal of Small Business and Entrepreneurship, 13(3), 29-56.

Nurlina, \& Muda. (2017). The analysis of the effects of capital expenditure and human development index on economic growth and poverty in east Aceh regency. International Journal of Economic Research, 14(16), 395-409.

Nwanna, I. O., \& Ivie, G. (2017). Effect of financial leverage on firm's performance: A study of Nigerian banks (2006-2015). Int'l J. Recent Scientific Research, 8(7), 18554-18564.

Saleh, M. M. A., \& Jawabreh, O. A. A. (2020). Role of environmental awareness in the application of environmental accounting disclosure in tourism and hotel companies and its impact on investor's decisions in Amman stock 
exchange. International Journal of Energy Economics and Policy, 10(2), 417-426. https://doi.org/10.32479/ijeep.8608

Saleh, M. M. A., Jawabreh, O. A. A., Alsarayreh, M. N., \& Malkawi, E. (2018). Environmental accounting as perspective for hotels of Aqaba special economic zone authority (ASEZA). Problems and Perspectives in Management, 16(4), 169-185. https://doi.org/10.21511/ppm.16(4).2018.15

Salehi, M., Talebnia, G., \& Ghorbani, B. (2011). A study of the relationship between liquidity and stock returns of companies listed in Tehran stock exchange. World Applied Sciences Journal, 12(9), 1403-1408.

Samo, A. H., \& Murad, H. (2019). Impact of liquidity and financial leverage on firm's profitability - an empirical analysis of the textile industry of Pakistan. Research Journal of Textile and Apparel, 23(4), 291-305. Retrieved from https://ezlibrary.ju.edu.jo:2057/10.1108/RJTA-09-2018-0055

Sivathaasan, N., Tharanika, R., Sinthuja, M., \& Hanitha, V. (2013). 9 Factors determining profitability: a study of selected manufacturing companies listed on Colombo stock exchange in Sri Lanka. European Journal of Business and Management, 5(27), 99-108.

Talha, M., Christopher, S. B., \& Kamalavalli, A. L. (2010). Sensitivity of profitability to working capital management: a study of Indian corporate hospitals. International Journal of Managerial and Financial Accounting, 2(3), 213-227.

Ton, Z. (2011). The effect of labor on profitability: the role of quality. https://doi.org/10.2139/ssrn.1269523

Wasiuzzaman, S. (2018). Determinants of liquidity in Malaysian SMEs: a quantile regression approach. International Journal of Productivity and Performance Management, 67(9), 1566-1584. Retrieved from https://ezlibrary.ju.edu.jo:2057/10.1108/IJPPM-12-2017-0354

Wedyan, L., Alrawashdeh, I., Jawabreh, O., \& Muneer, J. (2011). The extent of applying the accounting responsibility in aqaba hotels. International Research Journal of Finance and Economics, 69, 35-44.

\section{Copyrights}

Copyright for this article is retained by the author(s), with first publication rights granted to the journal.

This is an open-access article distributed under the terms and conditions of the Creative Commons Attribution license (http://creativecommons.org/licenses/by/4.0/). 